\title{
Major depressive disorder is associated with type 2 diabetes in patients with chronic hepatitis C infection
}

\author{
Luciana Rodrigues da CUNHA ${ }^{1,2}$, Maria Carolina Magalhães de CASTR01', Gabriela Silva DUARTE', \\ Graziela Cançado e NASCIMENTO' ${ }^{1}$, Gifone Aguiar ROCHA ${ }^{3}$ and Luciana Diniz SILVA ${ }^{1,4}$
}

Received: 9 April 2021 Accepted: 11 June 2021

\begin{abstract}
Background - Major depressive disorder (MDD) is commonly reported in patients with chronic hepatitis C (CHC); however, the factors behind the co-occurrence of these conditions have not been completely clarified yet. Objective - We aimed to evaluate the frequency of mental disorders in CHC patients and to investigate variables associated with MDD. Methods - CHC patients $(n=151)$ attending a referral Centre for hepatitis were evaluated using the Mini-International Neuropsychiatry Interview and the Cut-Annoyed-Guilty-Eye (CAGE) Questionnaire. Multivariate analysis was used to evaluate independent covariates associated with current MDD. Results - Seventy-six (50.3\%) patients had, at least, one current psychiatric diagnosis with $\mathrm{MDD}(33.1 \%)$ being the most common. Current MDD was independently associated with age ( $\leq 50 \mathrm{yr}$. $)(\mathrm{OR}=2.57 ; 95 \% \mathrm{CI}=1.25-5.29 ; P=0.01)$ and type 2 diabetes mellitus $(\mathrm{OR}=2.80,95 \% \mathrm{CI}=1.17-6.70 ; P=0.02)$. Cirrhosis was associated with type 2 diabetes mellitus $(\mathrm{OR}=5.09 ; 95 \% \mathrm{CI}=1.73-15.04$; $P=0.03)$ and current alcohol abuse/dependence $(\mathrm{OR}=2.54 ; 95 \% \mathrm{CI}=1.04-6.22 ; P=0.04)$. Discussion $-\mathrm{MDD}$ is associated with type 2 diabetes in $\mathrm{CHC}$ patients. Even in the direct-acting antivirals (DAAs) era, characterized by great perspectives for the first ample cure of a chronic viral infection, we should ensure that the screening for psychiatric disorders takes place in the course of routine clinical care of patients chronically infected with hepatitis $\mathrm{C}$ virus. Keywords - Hepatitis C; chronic psychiatric disorders; major depressive disorder; anxiety disorder; type 2 diabetes mellitus; alcohol abuse/dependence; non-alcohol drug abuse/dependence; cirrhosis.
\end{abstract}

\section{INTRODUCTION}

Hepatitis $\mathrm{C}$ virus (HCV) blood screening and the revolutionary development of direct-acting antivirals (DAAs) paved the way for saving millions of lives around the world ${ }^{(1,2)}$. The 2020 Nobel Prize in Physiology or Medicine honours the hepatitis $\mathrm{C}$ discoverers ${ }^{(1,2)}$. It should be highlighted that DAAs have been offering great perspectives for the first ample cure of a chronic infection in human, i.e., a sustained viral response rates that surpass $95.0^{\%} \%^{(3,4)}$.

Although outstanding changes in the management of patients with chronic hepatitis $\mathrm{C}(\mathrm{CHC})$, the frequency of advanced liver disease and hepatic related deaths are expected to rise around the world over the next 15 years $^{(5)}$. Furthermore, most countries have been focusing on treating patients in whom the $\mathrm{HCV}$ infection was already diagnosed without robust strategies to screen new hepatitis $C$ cases ${ }^{(6)}$.

Approximately $80.0 \%$ of acutely infected patients develop CHC, of whom, $20.0 \%$ will progress to liver cirrhosis and/or carcinoma hepatocellular after $2 / 3$ decades of viral infection ${ }^{(7)}$. Almost one quarter of all cases of hepatic cirrhosis and hepatocellular carcinoma worldwide were identified in individuals with $\mathrm{CHC}$, which accounted for 400,000 deaths per year in $2015^{(8)}$.

In addition, several $\mathrm{HCV}$-associated comorbidities have significantly contributed the health burden related to HCV. Among them, type 2 diabetes, insulin resistance, atherosclerosis, mixed cryoglobulinemia vasculitis, lymphoproliferative disorders, renal disease, sicca syndrome, rheumatoid arthritis-like polyarthritis, and autoantibody production ${ }^{(9)}$. An augmented prevalence of psychiatric disorders and symptoms, particularly fatigue, depression, anxiety, bipolar disorder and schizophrenia, has also been verified in individuals with $\mathrm{CHC}$ in comparison with general population ${ }^{(10)}$. Otherwise, increased risk for acquiring HCV has been identified in psychiatric populations. The prevalence of $\mathrm{HCV}$ infection among patients with chronic mental illnesses ranges from $0.4 \%$ to $38.0 \%{ }^{(11)}$.

Although the development of DAAs has been causing immense modifications in the treatment of $\mathrm{CHC}^{(3,4)}$, these innovations have a high $\operatorname{cost}^{\left({ }^{(3,4)}\right.}$ and represent an obstacle for many health systems around the world. Recently, Hengstet et al. (2016) demonstrated that DAA-induced viral clearance does not completely restore the altered cytokine and chemokine milieu in CHC patients ${ }^{(12)}$. Furthermore, in previous studies, the authors observed the persistence of neuropsychiatric impairment in patients with $\mathrm{CHC}$ despite the clearance of the virus ${ }^{(13,14)}$.

Therefore, the aim of the present study was to identify the frequency of mental disorders in outpatients with $\mathrm{CHC}$. We further investigated the association between demographic, clinical, lifestyle, biochemical, and virological variables and current major depressive disorder (MDD).

${ }_{1}^{1}$ Universidade Federal de Minas Gerais, Faculdade de Medicina, Ambulatório de Hepatites Virais, Instituto Alfa de Gastroenterologia, Belo Horizonte, MG, Brasil. ${ }^{2}$ Universidade Federal de Minas Gerais, Programa de Pós-Graduação em Neurociências, Instituto de Ciências Biológicas, Belo Horizonte, MG, Brasil. ${ }^{3}$ Universidade Federal de Minas Gerais, Faculdade de Medicina, Laboratório de Pesquisa em Bacteriologia, Belo Horizonte, MG, Brasil. ${ }^{4}$ Universidade Federal de Minas Gerais, Faculdade de Medicina, Departamento de Clínica Médica, Belo Horizonte, MG, Brasil.

Corresponding author: Luciana Diniz Silva. E-mail: lucianadinizsilva@ufmg.br 


\section{METHODS}

\section{Study population}

From 2013 to 2018 , we, prospectively, invited 178 consecutive outpatients with $\mathrm{CHC}$ attending the viral hepatitis outpatient Clinic of the University Hospital of Universidade Federal de Minas Gerais (UFMG), Belo Horizonte, Brazil. The Viral Hepatitis Outpatient Clinic is an outpatient care ambulatory of a metropolitan tertiary teaching hospital that admits patients for the treatment of chronic viral hepatitis $\mathrm{B}$ or $\mathrm{C}$.

\section{Patients}

The study was approved by the Ethics Committee of Federal University of Minas Gerais, UFMG (ETIC 0631.0.203.000-09).

The patients with $\mathrm{CHC}$ were screened for other hepatic diseases. The exclusion criteria were pregnancy, hepatic encephalopathy, hepatitis B virus (HBV)/HCV or HCV/human immunodeficiency virus (HIV) co-infection, recurrent MDD, current antiviral or antidepressant treatment, use of non-steroidal anti-inflammatory drugs or corticosteroids, and the presence of advanced disease such as chronic kidney disease, heart failure, chronic pulmonary disease, and neoplasia, including hepatocellular carcinoma.

The diagnosis of cirrhosis was based on standard clinical, biochemical, radiological, and histological parameters ${ }^{(15)}$. Compensated cirrhosis was defined as the absence of variceal bleeding, ascites, and oedema on physical examination; jaundice or symptomatic encephalopathy; and decompensated cirrhosis as the presence of any of these complications ${ }^{(16)}$. The Child-Turcotte-Pugh ${ }^{(17)}$ was scored for all compensated cirrhotic patients.

Twenty-seven patients were not included because one spontaneously cleared the virus, one had hepatic encephalopathy; one had $\mathrm{HBV} / \mathrm{HCV}$ co-infection and eight had chronic kidney disease; four refused to participate and twelve failed to complete the questionnaire. One hundred and fifty-one patients remained in the study. The patients were from a similar socioeconomic level, as assessed by a previously validated questionnaire ${ }^{(18)}$, which was based on income and educational level.

All included subjects underwent a psychiatric evaluation, by assessing the psychiatric history and mental status. Thereafter, the Brazilian version of the Mini International Neuropsychiatric Interview (M.I.N.I. Plus) was administered ${ }^{(19)}$. This instrument is a semi structured diagnostic interview comprising the primary Axis I Disorders of the Diagnostic and Statistical Manual of Mental Disorders IV (DSM IV) and the International Classification of Diseases (ICD-10), which was designed for clinical practice and research in psychiatric and primary care settings ${ }^{(20)}$. The diagnosis of the first episode of MDD and alcohol misuse was performed according to the ICD-10 and the DSM-IV (American Psychiatric Association, 1994) ${ }^{(20)}$. Regarding alcohol use, the individuals answered a self-administered questionnaire. The first part was the standard Cut-Annoyed-Guilty-Eye (CAGE) Questionnaire that consists of four items asking whether patients have ever tried to cut down on drinking, gotten annoyed with people asking about their drinking, felt guilty about drinking, or had an eye opener. The presence of two or more positive answers to the CAGE Questionnaire suggests an alcohol problem ${ }^{(21)}$. The second part consisted in responding a detailed questionnaire regarding past and current alcohol consumption in terms of amount, frequency, and duration of use.

The diagnosis of type 2 diabetes mellitus was based on documented use of oral hypoglycaemic medication or insulin; random plasma glucose levels $\geq 200 \mathrm{mg} / \mathrm{dL}$ in the presence of classic symptoms of hyperglycaemia or hyperglycaemic crisis; fasting plasma glucose $\geq 126 \mathrm{mg} / \mathrm{dL}$ on two occasions; 2 hours plasma glucose $\geq 200 \mathrm{mg} / \mathrm{dL}$ during oral glucose tolerance test or haemoglobin A1c $\geq 6.5 \%$ on two occasions ${ }^{(22)}$.

\section{Laboratory parameters}

Venous blood samples were obtained from each patient for $\mathrm{HCV}$ diagnosis and biochemical evaluation. Antibody to $\mathrm{HCV}$ was investigated by a commercial enzyme-linked immunosorbent assay (ELISA) (AxSYM HCV, version 3.0; Abott GmbH \& Co., Wiesbaden, Germany), and HCV status was confirmed by a qualitative polymerase chain reaction for HCV RNA (AMPLICOR 2.0 assay; Roche Diagnostics, Branchburg, NJ) according to the manufacturers' instructions. HCV genotyping and viral load were determined by using a commercial test (Cobas TaqMan HCV test V.2.0; Roche Molecular Systems, Pleasanton, CA) and a line probe assay (VERSANT HCV genotyping assays; Bayer's Diagnostic Corporation, Tarrytown, NY), respectively. The assays were carried out according to the manufacturers' recommendations. Viral load and $\mathrm{HCV}$ genotyping are only performed in patients who fulfil the criteria for antiviral therapy adopted in our service, being available in $74.8 \%$ of the included patients.

Alanine aminotransferase (ALT), aspartate aminotransferase (AST) and serum albumin were evaluated by routine laboratory methods.

\section{Data analyses}

Data were analysed using the Statistical Package for Social Sciences, version 20.0 (SPSS Inc., Chicago, IL).

Descriptive statistics were used to provide information regarding the demographic and disease-specific characteristics. The Shapiro-Wilk test was used to evaluate whether the data were normally distributed. For the comparison of the percentages and the median, the asymptotic Pearson's chi-square test and the MannWhitney U test were used, respectively.

Logistic regression models were created to quantify independent associations between the psychiatric diagnosis, MDD, and the following variables: sociodemographic, clinical and lifestyle data. All variables with $P \leq 0.25$ in the univariate analysis were included in the full models of logistic regression using the additive and subtractive stepwise approach. Odds ratio (OR) and 95.0\% confidence interval $(95 \% \mathrm{CI})$ were used as an estimate of the risk. The Hosmer-Lemeshow test was used to assess the adequacy of the models. Variables that had more than $10.0 \%$ missing data were not selected for the models of multivariate analysis.

Logistic regression models were created to quantify the independent association between the cirrhosis and the following variables: clinical comorbidities, and psychiatric disorders data, adjusted by age and sex.

$P$ values $\leq 0.05$ were considered significant.

\section{RESULTS}

\section{Characteristics of the study population}

The sociodemographic, clinical, virological, biochemical and lifestyle data of the $\mathrm{CHC}$ patients with $(n=76)$ and without $(n=75)$ current psychiatric disorders are shown in TABLE 1. Patients with psychiatric disorders were younger than those without these disorders $(P=0.03)$. The frequency of current smoking was significantly 
TABLE 1. Sociodemographic, clinical, virological, biochemical and lifestyle data of the chronic hepatitis $C$ patients with $(n=76)$ and without $(\mathrm{n}=75)$ current psychiatric disorders.

\begin{tabular}{|c|c|c|c|}
\hline \multirow[t]{2}{*}{ Variables } & \multicolumn{2}{|c|}{$\begin{array}{l}\text { Current psychiatric } \\
\text { disorders }\end{array}$} & \multirow[b]{2}{*}{$P$} \\
\hline & Present & Absent & \\
\hline \multicolumn{4}{|l|}{ Sociodemographic data n (\%) } \\
\hline Sex & & & 0.47 \\
\hline Male & $33(43.4)$ & $37(49.3)$ & \\
\hline Female & $43(56.6)$ & $38(50.7)$ & \\
\hline Age (years) median (IQR)* & $50.5(15)$ & $55.0(15)$ & 0.03 \\
\hline Marital status n (\%) & & & 0.10 \\
\hline Single & $18(23.7)$ & $24(32.0)$ & \\
\hline Married & $46(60.5)$ & $45(60.0)$ & \\
\hline Separated/divorced & $6(7.9)$ & $3(4.0)$ & \\
\hline Widowed & $6(7.9)$ & $3(4.0)$ & \\
\hline Educational level n (\%) & & & 0.12 \\
\hline$\leq 9$ years & $43(56.6)$ & $33(44.0)$ & \\
\hline$>9$ years & $33(43.4)$ & $42(56.0)$ & \\
\hline $\begin{array}{l}\text { Total household income/month } \\
\mathrm{n}(\%)^{\mathrm{a}}\end{array}$ & & & 0.29 \\
\hline$\leq 1$ minimum wage & $17(22.4)$ & $12(16.0)$ & \\
\hline $1.001-3$ minimum wages & $35(46.1)$ & $32(42.7)$ & \\
\hline $3.001-5$ minimum wages & $13(17.1)$ & $20(26.7)$ & \\
\hline$>5$ minimum wages & $11(14.5)$ & $11(14.7)$ & \\
\hline \multicolumn{4}{|l|}{ Clinical Comorbidities n (\%) } \\
\hline Type 2 diabetes mellitus & $17(22.4)$ & $11(14.7)$ & 0.23 \\
\hline Hypertension & $25(32.9)$ & $30(40.0)$ & 0.37 \\
\hline Liver disease stage $\mathrm{n}(\%)$ & & & 0.30 \\
\hline Chronic hepatitis & $63(82.9)$ & $57(76.0)$ & \\
\hline Cirrhosis & $13(17.1)$ & $18(24.0)$ & \\
\hline Cirrhosis stage - Child A/B/C & $9 / 3 / 1$ & $14 / 3 / 1$ & 0.83 \\
\hline \multicolumn{4}{|l|}{ Virological parameters } \\
\hline \multicolumn{4}{|l|}{ Viral load ${ }^{\mathrm{b}}$} \\
\hline $\begin{array}{l}\text { HCV-RNA (IU/mL) median } \\
\text { (IQR) }\end{array}$ & $\begin{array}{c}698,000 \\
(2,014,842)\end{array}$ & $\begin{array}{c}580,500 \\
(1,209,211)\end{array}$ & 0.77 \\
\hline Genotype $(1 \mathrm{a}, 1 \mathrm{~b}, 3 \mathrm{a}) \mathrm{n}(\%)^{\mathrm{b}}$ & $48(92.3)$ & $60(98.4)$ & 0.26 \\
\hline Genotype others $\mathrm{n}(\%)^{\mathrm{b}, \mathrm{c}}$ & $4(7.7)$ & $1(1.6)$ & \\
\hline \multicolumn{4}{|c|}{ Biochemical parameters median (IQR) } \\
\hline ALT (U/L) & $61(50.0)$ & $60(50.0)$ & 0.63 \\
\hline AST (U/L) & $56(43.5)$ & $63(46)$ & 0.60 \\
\hline Albumin $(\mathrm{g} / \mathrm{dL})$ & $4.3(0.5)$ & $4.3(0.8)$ & 0.51 \\
\hline \multicolumn{4}{|l|}{ Lifestyle data n (\%) } \\
\hline \multicolumn{4}{|l|}{ Alcohol use } \\
\hline At least once/adult lives & $65(85.5)$ & $60(80.0)$ & 0.37 \\
\hline Current use & $24(31.6)$ & $12(16.0)$ & 0.06 \\
\hline Positive CAGE screen ${ }^{\mathrm{d}, *}$ & $21(28.8)$ & $12(15.7)$ & 0.03 \\
\hline \multicolumn{4}{|l|}{ Smoking } \\
\hline Previous & $41(54.7)$ & $38(52.1)$ & 0.75 \\
\hline Current use* & $18(24.3)$ & $8(10.7)$ & 0.03 \\
\hline
\end{tabular}

a: the Brazilian national minimum wage was $\mathrm{R} \$ 724.00$ (\$211.70) (minimum wage law: $8.166 / 2013)$ in 2014. b: data from $113(74.8 \%)$ patients; $c: 1 a+1 b, 2 b, 2 a+2 b$; d: CAGE (cut down on drinking, gotten angry with people asking about their drinking, felt guilty about drinking or had an eye opener). n: number of subjects; IQR, interquartile range; $\mathrm{CHC}$ : chronic hepatitis C; ALT: alanine aminotransferase; AST: aspartate aminotransferase; CAGE: Cut-Annoyed-Guilty-Eye. $* P \leq 0.05$. higher $(P=0.03)$ and current alcohol use tended to be significantly more frequent $(P=0.06)$ in patients with psychiatric disorders. Positive CAGE screen was associated with psychiatric disorders in patients with $\mathrm{CHC}(P=0.03)$. At the time of the study, no patient was receiving interferon-based drug therapy or DAAs.

\section{Psychiatric disorders}

Prevalence of current and lifetime psychiatric disorders are summarized in TABLE 2 . The psychiatric diagnoses included six categories, anxiety disorders, mood disorders, psychotic disorders, alcohol use disorders, non-alcohol substance use disorders (abuse and/or dependence) and other psychiatric disorders. Fifty of 151 $\mathrm{CHC}$ patients $(33.1 \%)$ had current MDD, i.e., 50 of $76(65.8 \%)$ patients diagnosed with current psychiatric disorder. MDD was the most common psychiatric disorder observed among these patients. Seventeen of the $151(11.2 \%)$ patients had at least one current anxiety disorder (TABLE 2).

TABLE 2. Current and lifetime psychiatric disorders diagnosed in patients with chronic hepatitis $C(n=151)$.

Psychiatric diagnoses $\quad$ Current $\mathrm{n}(\%) \quad$ Lifetime $\mathrm{n}(\%)$

Any psychiatric disorders $\quad 76(100.0) \quad 102(100.0)$

Anxiety disorders

$\begin{array}{lcc}\text { Generalized anxiety } & 17(22.4) & 17(16.7) \\ \text { Panic } & 4(5.3) & 4(3.9) \\ \text { Obsessive compulsive } & 2(2.6) & 2(2.0) \\ \text { Post-traumatic stress } & 1(1.3) & 1(1.0) \\ \text { Other anxiety disorder } & 15(19.7) & 15(14.7)\end{array}$

Mood disorders

$\begin{array}{lcc}\text { Major depressive } & 50(65.8) & 27(26.5) \\ \text { Bipolar } & 1(1.3) & 1(1.0) \\ & & \\ \text { Psychotic disorders } & 6(7.9) & 6(5.9)\end{array}$

Substance use disorders (abuse and/or dependence)

$\begin{array}{lcc}\text { Alcohol } & 17(22.4) & 46(45.0) \\ \text { Non-alcohol } & 7(9.2) & 36(35.3) \\ & & \\ \text { Other psychiatric disorders } & 2(2.6) & 2(2.0)\end{array}$

Lifetime alcohol use disorder was verified in 46/151 (30.5\%) of the patients. Twenty-seven patients with drug addiction $(27 / 36$; $75.0 \% ; P<0.001)$ meeting criteria for alcohol abuse and/or dependence. Cocaine, crack and cannabis were the most commonly used illicit drugs. Alcohol abuse $(P<0.001)$ and non-alcohol substance abuse $(P=0.005)$ were more frequently observed in men than in women $(58.6 \%$ vs $11.1 \%)$ and $(34.3 \%$ vs $14.8 \%)$, respectively. 
Individuals who received diagnosis of alcohol abuse and/or dependence $(49.3 \pm 8.3 \mathrm{yr}$.) were younger $(P=0.002)$ than those without this psychiatric disorder $(54.6 \pm 11.9 \mathrm{yr}$.).

\section{Factors associated with current major depressive disorder in patients with chronic hepatitis C}

In the univariate analysis, age, educational level, type 2 diabetes mellitus, positive CAGE screen as well as current smoking use were selected. Younger age and type 2 diabetes mellitus remained significantly and independently associated with current major depressive disorder in the multivariate analysis (TABLE 3).

TABLE 3. Variables associated with current major depressive disorder in patients with chronic hepatitis $\mathrm{C}$

\begin{tabular}{ccccc}
\hline Variables & $\begin{array}{c}\text { Univariate } \\
\text { analysis }\end{array}$ & \multicolumn{3}{c}{$\begin{array}{c}\text { Multivariate } \\
\text { analysis }\end{array}$} \\
\hline $\boldsymbol{P}$ & OR & $95 \%$ CI & $P$
\end{tabular}

Sociodemographic data

\begin{tabular}{lcccc} 
Age ( $\leq 50$ years $)$ & 0.02 & 2.57 & $1.25-5.29$ & 0.01 \\
Marital status & 0.43 & - & - & - \\
$\quad$ Educational level & 0.15 & 1.39 & $0.66-2.91$ & 0.38 \\
$\begin{array}{l}\text { Clinical comorbidities } \\
\quad \text { Type 2 diabetes mellitus }\end{array}$ & 0.05 & 2.80 & $1.17-6.70$ & 0.02 \\
$\begin{array}{l}\text { Lifestyle data } \\
\text { Positive CAGE screen }\end{array}$ & 0.11 & 1.31 & $0.55-3.11$ & 0.55 \\
Current smoking use & 0.13 & 1.77 & $0.72-4.33$ & 0.21 \\
\hline
\end{tabular}

a: CAGE (cut down on drinking, gotten angry with people asking about their drinking, felt guilty about drinking, or had an eye opener). CAGE: Cut-Annoyed-Guilty-Eye.

\section{Factors associated with cirrhosis in patients with chronic hepatitis $\mathbf{C}$}

In the univariate analysis, type 2 diabetes mellitus, current anxiety disorders and current alcohol abuse and/or dependence were selected. In the multivariate analysis, type 2 diabetes mellitus and current alcohol abuse/dependence remained significantly and independently associated with cirrhosis (TABLE 4).

\section{HCV viral load, HCV genotype and the psychiatric disorders in patients with hepatitis $\mathrm{C}$}

Neither the viral load nor the HCV genotype was associated with the psychiatric disorders in patients with hepatitis $\mathrm{C}$.

\section{DISCUSSION}

To the best of our knowledge, this is the first study to demonstrate that MDD is associated with type 2 diabetes in non-cirrhotic and compensated cirrhotic patients with $\mathrm{CHC}$. Growing body of evidence has shown that HCV infection not only causes hepatic cirrhosis and hepatocarcinoma but also is associated with several extrahepatic manifestations, including neuropsychiatric disorders. Yovtcheva et al. (2001) in a pioneering study, demonstrated a strong association between HCV infection and psychiatric disorders $^{(23)}$. Remarkably, the 2020 Nobel Prize in Physiology or Medicine highlighted the critical significance of hepatitis $\mathrm{C}$ in world health ${ }^{(24)}$. Even in the face of development of safe, well tolerated, and highly effective direct-acting antiviral agents that promote a cure of the chronic infection in more than $95.0 \%$ of patients ${ }^{(3,4,24)}$, several aspects of HCV-related psychiatric illnesses have not been completely clarified.

A strength of our study was that we studied only patients with $\mathrm{CHC}$ without decompensated conditions as encephalopathy, ascites, gastrointestinal bleeding, and infections, which might interfere in the brain function. In addition, the depressive disorder was diagnosed by a psychiatrist, using a detailed psychiatric approach in combination with a semi-structured interview validated in Portuguese $^{(19)}$ and widely used by Brazilian researchers ${ }^{(25)}$. Another strength is that we performed logistic regression models to analyse the associations between current MDD and sociodemographic, clinical, and lifestyle variables. One limitation is that psychiatric evaluation of non-HCV chronically infected patients with type 2 diabetes of the same geographic area was not available, therefore an epiphenomenon should not be completely ignored.

It has been shown that the prevalence of depression was moderately and markedly increased in pre-diabetic and diabetic patients, respectively, when these subjects were compared to healthy individuals ${ }^{(26,27)}$. Concerning the hepatitis $\mathrm{C}$ scenario, depressive disorders $^{(28-30)}$ and type 2 diabetes $^{(31,32)}$ are both associated with $\mathrm{HCV}$ infection. Especially, $\mathrm{CHC}$ patients with diabetes mellitus

TABLE 4. Variables associated with cirrhosis in patients with chronic hepatitis C.

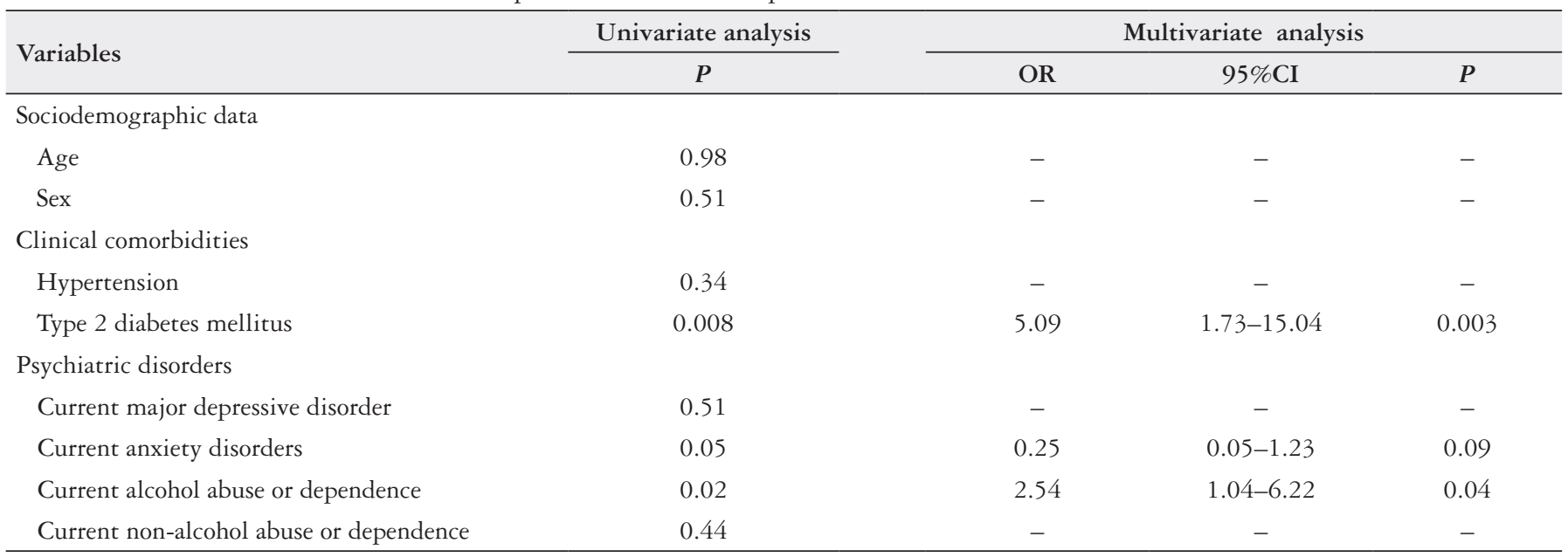


are likely to have a more complicated course of hepatopathy such as cirrhosis and carcinoma hepatocellular ${ }^{(31,32)}$. In the study population, the presence of cirrhosis was independently associated with current alcohol abuse/dependence as well as type 2 diabetes mellitus.

It is important to bear in mind that inflammation and host immune response to HCV may contribute to the pathophysiology and progression of psychiatric disorders. This hypothesis may shed light on the role played by the host's immune response in HCVrelated extrahepatic manifestations. Given the potential relevance of cytokines in mediating depressive symptoms ${ }^{(33)}$ and diabetes mellitus clinical course ${ }^{(27)}$, it might be speculated that inflammatory mediators are overexpressed in $\mathrm{CHC}$ patients with concurrent type 2 diabetes and depressive disorder. Recently, we demonstrated that the IL-10 low producer ATA haplotype was associated with the first major depressive episode ${ }^{(34)}$ and combined polymorphisms of IL-6174GG genotype, high-producer IL-6 phenotype, and IL-10 ATA haplotype were associated with a poor quality of life in patients with $\mathrm{CHC}^{(31)}$. More recently, our group also demonstrated that patients with chronic HCV infection carrying IL-6-174GG homozygous genotype were at increased risk of type 2 diabetes ${ }^{(35)}$. These findings suggest that an imbalance between pro-inflammatory and anti-inflammatory cytokines might induce an immune activation, and consequently, generates extrahepatic disorders as depressive symptoms as well as glucose intolerance.

Besides a high prevalence of psychiatric disorders found in our outpatients with $\mathrm{CHC}$, irrespective of HCV antiviral therapy, notably, psychiatric illness overlap was also a common finding. At least, $35.8 \%$ of them suffer from two or more psychiatric disorders. Among the lifetime psychiatric illness, alcohol use disorder (30.5\%), non-alcohol drug disorder (23.8\%), MDD (17.9\%) and generalized anxiety $(11.3 \%)$ were the most prevalent disorders identified in agreement with previous studies ${ }^{(23,28)}$. However, the patients evaluated in those studies were veterans followed at the US Department of Veterans Affairs Hospital, where a large number of them were male and had a high prevalence of psychiatric illness and history of substance abuse ${ }^{(23,28)}$ consequently, in CHC setting, health professionals have a great challenge in the management of these patients because two or more psychiatric disorders associated with clinical comorbidities, can be present. Additionally, the alcohol and/or non-alcohol substance were common in the study population. Thus, these findings precluded the possibility to recognize the influence of each specific variable in a particular psychiatric disorder occurrence. On other hand, the overlapping between host-, $\mathrm{HCV}$ - and environmental- related factors reflects the complexities of analysing chronic diseases in the real world ${ }^{(36)}$.

Preceding HCV infection significantly increases the risk of developing psychiatric comorbidities. On the other hand, patients with psychiatric illness are at an increased risk of acquiring HCV infection $^{(11)}$. Thus, this two-way interface, i.e., the relationship linking HCV and neuropsychiatric manifestations, is possibly determined by complex and multifaceted interactions among the hepatitis virus, the environment and the host.
Our current data show that neither different HCV genotypes nor viral load was significantly associated with psychiatric comorbidities. In a systematic review conducted by Perry et al. (2008) neither the viral load nor the HCV genotype was associated with cognitive impairment in patients with $\mathrm{CHC}^{(37)}$. Despite the pathogenesis of HCV-related psychiatric symptoms has not been completely understood, evidences that the virus is able to cross the blood-brain-barrier should not be disregarded ${ }^{(38)}$.

In summary, we have clearly demonstrated that psychiatric disorders are prevalent in patients with CHC. Even in the DAAs era, characterized by great perspectives for the first ample cure of a chronic viral infection in humans ${ }^{(3,4)}$, we should pursue the patient care integration. Therefore, efforts should be made to ensure that the screening for psychiatric disorders takes place in the course of routine clinical care. Considering the hepatitis $\mathrm{C}$ as a systemic disease, integrated clinical/psychiatric/psychological care must be enhanced in the management of individuals chronically infected with HCV. Beyond the virus and the liver disease, the psychiatric disorders must be recognized in patients with $\mathrm{CHC}$. This approach will able to prioritize the patients' needs, values and goals ${ }^{(39)}$.

Concerning the association between current MDD and type 2 diabetes our patients with $\mathrm{CHC}$ were recruited from a referral centre and, consequently, may not be representative of all chronically HCV-infected patients. Furthermore, the cross-sectional nature of the investigation hindered the likelihood to recognize any cause-effect relationship between current MDD and demographic, clinical, lifestyle, and virological variables in patients with $\mathrm{CHC}$.

In conclusion, MDD is associated with type 2 diabetes in $\mathrm{CHC}$ patients. Even in the direct-acting antivirals (DAAs) era, characterized by great perspectives for the first ample cure of a chronic viral infection, we should ensure that the screening for psychiatric disorders takes place in the course of routine clinical care of patients chronically infected with hepatitis $\mathrm{C}$ virus (HCV).

\section{Authors' contribution}

Cunha LR: designed research, project conception, development of overall research plan, and study oversight. Castro MCM: conducted research, hands-on conduct of the experiments and data collection. Duarte GS: conducted research, hands-on conduct of the experiments and data collection. Nascimento GC: conducted research, hands-on conduct of the experiments and data collection. Rocha GA: designed research, project conception, development of overall research plan, and study oversight. Silva LD: designed research, project conception, development of overall research plan, and study oversight.

\section{Orcid}

Luciana Rodrigues da Cunha: 0000-0001-5006-6129.

Maria Carolina Magalhães de Castro: 0000-0001-7371-1979.

Gabriela Silva Duarte: 0000-0003-1755-3253.

Graziela Cançado e Nascimento: 0000-0003-2801-0326.

Gifone Aguiar Rocha: 0000-0002-1858-3166.

Luciana Diniz Silva: 0000-0003-0061-7361. 
Cunha LR, Castro MCM, Duarte GS, Nascimento GC, Rocha GA, Silva LD. O transtorno depressivo maior está associado ao diabetes mellitus tipo 2 em pacientes com hepatite C crônica. Arq Gastroenterol. 2021;58(4):476-82.

RESUMO - Contexto - O transtorno depressivo maior (TDM) é comumente detectado em pacientes com hepatite C crônica. Entretanto, fatores potencialmente associados à coocorrência destas condições não são completamente conhecidos. Objetivo - Avaliar a frequência de transtornos mentais em pacientes com hepatite $\mathrm{C}$ crônica e investigar variáveis associadas ao TDM. Métodos - Pacientes com hepatite $\mathrm{C}$ crônica $(\mathrm{n}=151)$ atendidos em um centro de referência para hepatite foram avaliados usando o Mini-International Neuropsychiatry Interview e o questionário Cut-Annoyed-Guilty-Eye (CAGE). Análise multivariada foi usada para avaliar as covariáveis independentes associadas ao TDM atual. Resultados - Setenta e seis (50,3\%) pacientes apresentaram pelo menos um diagnóstico psiquiátrico atual; dentre eles destaca-se o TDM (33,1\%). TDM atual foi independentemente associado à idade ( $\leq 50$ anos) $(\mathrm{OR}=2,57$; IC95\% $=1,25-5,29 ; P=0,01)$ e diabetes mellitus tipo $2(\mathrm{OR}=2,80, \mathrm{IC} 95 \%=1,17-6,70 ; P=0,02)$. Cirrose foi associada ao diabetes mellitus tipo $2(\mathrm{OR}=5,09 ; \mathrm{IC} 95 \%=1,73-15,04 ; P=0,03)$ e abuso/dependência de álcool atual $(\mathrm{OR}=2,54 ; \mathrm{IC} 95 \%=1,04-6,22$; $P=0,04)$. Discussão - TDM está associado a diabetes tipo 2 em pacientes com hepatite $\mathrm{C}$ crônica. Em vigência da era dos antivirais de ação direta, caracterizada por grandes perspectivas para a primeira cura ampla de uma infecção viral crônica, devemos assegurar que a triagem dos transtornos psiquiátricos ocorra durante o atendimento clínico de rotina de pacientes com infecção crônica pelo vírus da hepatite C.

Palavras-chave - Hepatite C; transtornos psiquiátricos crônicos; transtorno depressivo maior; transtorno de ansiedade; diabetes mellitus tipo 2; abuso/ dependência de álcool; abuso/dependência de substâncias não alcoólicas; cirrose hepática.

\section{REFERENCES}

1. Burki T. Nobel Prize for hepatitis C virus discoverers. Lancet. 2020;396:1058. doi: 10.1016/S0140-6736(20)32111-5.

2. Gretchen-Vogel. Medicine Nobel honours three scientists for discoveries on hepatitis C virus. Available from: https://www.sciencemag.org/news/2020/10/ medicine-nobel-honors-three-scientists-discoveries-hepatitis-c-virus. doi:10.1126/ science.abf0538.

3. Baumert TF, Berg T, Lim JK, Nelson DR. Status of Direct-Acting Antiviral Therapy for Hepatitis C Virus Infection and Remaining Challenges. Gastroenterology. 2019;156:431-45. doi: 10.1053/j.gastro.2018.10.024.

4. Daniel KE, Saeian K, Rizvi S. Real-world experiences with direct-acting antiviral agents for chronic hepatitis C treatment. J Viral Hepat. 2020;27:195-204. doi: 10.1111/jvh.13218.

5. Hatzakis A, Chulanov V, Gadano AC, Bergin C, Ben-Ari Z, Mossong J, et al. The present and future disease burden of hepatitis $\mathrm{C}$ virus (HCV) infections with today's treatment paradigm - volume 2. J Viral Hepat. 2015;22 (Suppl 1):26-45. doi: $10.1111 /$ jvh.12351.

6. Razavi H. Global Epidemiology of Viral Hepatitis. Gastroenterol Clin North Am. 2020;49:179-89. doi: 10.1016/j.gtc.2020.01.001.

7. Alter HJ, Seeff LB. Recovery, persistence, and sequelae in hepatitis $\mathrm{C}$ virus infection: a perspective on long-term outcome. Semin Liver Dis. 2000;20:17-35. doi: $10.1055 / \mathrm{s}-2000-9505$.

8. Global Hepatitis Report 2017. Geneva: World Health Organization; 2017 Available from: https://www.who.int/hepatitis/publications/global-hepatitis-report2017/en/

9. Negro F, Forton D, Craxì A, Sulkowski MS, Feld JJ, Manns MP. Extrahepatic morbidity and mortality of chronic hepatitis C. Gastroenterology. 2015;149:134560. doi: 10.1053/j.gastro.2015.08.035.

10. Schaefer M, Capuron L, Friebe A, Diez-Quevedo C, Robaeys G, Neri S, et al. Hepatitis C infection, antiviral treatment and mental health: a European expert consensus statement. J Hepatol. 2012;57:1379-90. doi: 10.1016/j.jhep.2012.07.037.

11. Campos LN, Guimarães MD, Carmo RA, Melo AP, Oliveira HN, Elkington K, et al. HIV, syphilis, and hepatitis $B$ and $C$ prevalence among patients with mental illness: a review of the literature. Cad Saude Publica. 2008;24(Suppl 4):s607-20.

12. Hengst J, Falk CS, Schlaphoff V, Deterding K, Manns MP, Cornberg M, et al. Direct-acting antiviral-induced hepatitis $\mathrm{C}$ virus clearance does not completely restore the altered cytokine and chemokine milieu in patients with chronic hepatitis C. J Infect Dis. 2016;214:1965-74. doi.org/10.1093/infdis/jiw457.

13. Dirks M, Pflugrad H, Haag K, Tillmann HL, Wedemeyer H, Arvanitis D, et al Persistent neuropsychiatric impairment in $\mathrm{HCV}$ patients despite clearance of the virus?! J Viral Hepat. 2017;24:541-50. doi: 10.1111/jvh.12674.

14. Gallach M, Vergara M, da Costa JP, Miquel M, Casas M, Sanchez-Delgado J, et al Impact of treatment with direct-acting antivirals on anxiety and depression in chronic hepatitis C. PLoS One. 2018;13:e0208112. doi: 10.1371/journal.pone.0208112.
15. Tsochatzis EA, Bosch J, Burroughs AK. Liver cirrhosis. Lancet. 2014;383:174961. doi: 10.1016/S0140-6736(14)60121-5.

16. D'Amico G, Pasta L, Morabito A, D'Amico M, Caltagirone M, Malizia G, et al. Competing risks and prognostic stages of cirrhosis: a 25-year inception cohort study of 494 patients. Aliment Pharmacol Ther. 2014;39:1180-93, doi. org/10.1111/apt.12721.

17. Child CG, Turcotte JG. Surgery and portal hypertension. Major Probl Clin Surg. 1964;1:1-85.

18. Silva LD, Cunha CC, Cunha LR, Araújo RF, Barcelos VM, Menta PL, et al. Depression rather than liver impair-ment reduces quality of life in patients with hepati-tis C. Rev Bras Psiquiatr. 2015;37:21-30. doi.org/10.1590/1516-4446-2014-1446.

19. Amorim P. Mini International Neuropsychiatric Interview (MINI): validation of a short structured diagnostic psychiatric interview. Rev Bras Psiquiatr. 2000;22:10615. doi.org/10.1590/S1516-44462000000300003.

20. Sheehan DV, Lecrubier Y, Sheehan KH, Amorim P, Janavs J, Weiller E, et al. The Mini-International Neuropsychiatric Inter-view (M.I.N.I.): the development and validation of a structured diagnostic psychiatric interview for DSM-IV and ICD-10. J Clin Psychiatry. 1998;59(Suppl 20):22-33; quis 34-57.

21. Dhalla S, Kopec JA. The CAGE questionnaire for alcohol misuse: a review of reliability and validity studies. Clin Invest Med. 2007;30:33-41. doi: 10.25011/ cim.v30i1.447.

22. American Diabetes Association. 2. Classification and Diagnosis of Diabetes: Standards of Medical Care in Diabetes-2018. Diabetes Care. 2018;41(Suppl 1):S13-S27. doi: 10.2337/dc18-S002

23. Yovtcheva SP, Rifai MA, Moles JK, Van der Linden BJ. Psychiatric comorbidity among hepatitis C-positive patients. Psychosomatics. 2001;42:411-5. doi: 10.1176/ appi.psy.42.5.411.

24. Hoofnagle JH, Feinstone SM. The Discovery of Hepatitis C - The 2020 Nobel Prize in Physiology or Medicine. N Engl J Med. 2020;383:2297-9. doi: 10.1056/ NEJMp2031110.

25. Batista-Neves SC, Quarantini LC, de Almeida AG, Bressan RA, Lacerda AL, de-Oliveira IR, et al. High frequency of unrecognized mental disorders in HCV-infected patients. Gen Hosp Psychiatry. 2008;30:80-2. doi: 10.1016/j. genhosppsych.2007.08.014

26. Chen S, Zhang Q, Dai G, Hu J, Zhu C, Su L, Wu X. Association of depression with pre-diabetes, undiagnosed diabetes, and previously diagnosed diabetes: a meta-analysis. Endocrine. 2016;53:35-46. doi: 10.1007/s12020-016-0869-x.

27. Moulton CD, Pickup JC, Ismail K. The link between depression and diabetes: the search for shared mechanisms. Lancet Diabetes Endocrinol. 2015;3:461-71. doi: 10.1016/S2213-8587(15)00134-5.

28. El-Serag HB, Kunik M, Richardson P, Rabeneck L. Psychiatric disorders among veterans with hepatitis C infection. Gastroenterology. 2002;123:476-82. doi: $10.1053 /$ gast.2002.34750. 
29. Lee K, Otgonsuren M, Younoszai Z, Mir HM, Younossi ZM. Association of chronic liver disease with depression: a population-based study. Psychosomatics. 2013;54:52-9. doi.org/10.1016/j.psym.2012.09.005.

30. Vieira DA, da Cunha LR, da Silva CB, Almeida MTB, Gomes AD, de Faria CLL Jr, et al. The combined polymorphisms of interleukin-6-174GG genotype and interleukin-10 ATA haplotype are associated with a poor quality of life in patients with chronic hepatitis C. Qual Life Res. 2019;28:1531-42. doi: 10.1007/ s11136-019-02129-5.

31. Negro F, Alaei M. Hepatitis C virus and type 2 diabetes. World J Gastroenterol. 2009;15:1537-47. doi: 10.3748/wjg.15.1537.

32. Li J, Gordon SC, Rupp LB, Zhang T, Trudeau S, Holmberg SD, et al. CHeCS Investigators. Sustained virological response to hepatitis $\mathrm{C}$ treatment decreases the incidence of complications associated with type 2 diabetes. Aliment Pharmacol Ther. 2019;49:599-608. doi: 10.1111/apt.15102.

33. Loftis JM, Huckans M, Ruimy S, Hinrichs DJ, Hauser P. Depressive symptoms in patients with chronic hepatitis $\mathrm{C}$ are correlated with elevated plasma levels of interleukin-1 beta and tumour necrosis factor-alpha. Neurosci Lett. 2008;430:2648. doi: 10.1016/j.neulet.2007.11.001.
34. Cunha LRD, Vieira DA, Giampietro YG, Gomes AD, Lopes de Faria CL Jr, Freire de Melo F, et al. Interleukin-10 promoter gene polymorphisms are associated with the first major depressive episode in chronic hepatitis $\mathrm{C}$ patients. Clin Res Hepatol Gastroenterol. 2019;43:417-26. doi: 10.1016/j.clinre.2018.11.015.

35. da Silva CB, Vieira DA, de Melo LF, Chagas ALS, Gomes AD, de Faria CLL $\mathrm{Jr}$, et al. Interleukin-6-174G/C polymorphism is associated with a decreased risk of type 2 diabetes in patients with chronic hepatitis $\mathrm{C}$ virus. World $\mathrm{J}$ Hepatol. 2020;12:137-48. doi: 10.4254/wjh.v12.i4.137.

36. Helbling B, Overbeck K, Gonvers JJ, Malinverni R, Dufour JF, Borovicka J, et al. Swiss Hepatitis C Cohort Study. Host- rather than virus-related factors reduce health-related quality of life in hepatitis C virus infection. Gut. 2008;57:1597-603. doi: 10.1136/gut.2007.142844.

37. Perry W, Hilsabeck RC, Hassanein TI. Cognitive dysfunction in chronic hepatitis C: a review. Dig Dis Sci. 2008;53:307-21. doi: 10.1007/s10620-007-9896-Z.

38. Fletcher NF, Wilson GK, Murray J, Hu K, Lewis A, Reynolds GM, et al. Hepatitis $\mathrm{C}$ virus infects the endothelial cells of the blood-brain barrier. Gastroenterology. 2012;142:634-43. doi.org/10.1053/j.gastro.2011.11.028.

39. Verma M, Navarro V. Patient-centred care: A new paradigm for chronic liver disease. Hepatology. 2015;62:988-90. doi: 10.1002/hep.28022. 